\title{
Accuracy of Pallor in the Diagnosis of Anemia in Children Aged 6 Months to 5 Years
}

\author{
Anand Chaudhary ${ }^{1}$, Saiprasad Onkareshwar Kavthekar', Mohan Anantrao Patil ${ }^{3}$, Bhuvan Kumar Singh ${ }^{4}$ \\ ${ }^{1} J u n i o r$ Resident, Department of Pediatrics, D Y Patil Medical Collage and Hospital, Kolhapur Maharashtra416006, (India), ${ }^{2}$ Associate Professor, Department of Pediatrics, \\ D Y Patil Medical Collage and Hospital, Kolhapur Maharashtra 416006, (India), ${ }^{3}$ Professor, Department of Pediatrics, D Y Patil Medical Collage and Hospital, Kolhapur \\ Maharashtra 416006, (India), ${ }^{4}$ Junior Resident, Department of Pediatrics, D. Y. Patil Medical College and Hospital, Kolhapur, Maharashtra 416006.
}

\section{Abstract}

Background: The diagnosis and management of anemia largely depends on clinical assessment for pallor. Pallor is explained as decreased colour of the skin and mucous membranes. Aims and Objectives: To study sensitivity, specificity and predictive value of pallor at palpebral conjunctiva, tongue, nail bed and palm in diagnosing anemia and correlate pallor with hemoglobin. Subjects and Methods: 400 children aged between 6 months to 5 years out of which 200 having pallor (Cases) and 200 no pallor (Controls), admitted at Department of Pediatrics, D.Y.Patil Medical college and hospital, Kolhapur from $1^{\text {st }}$ October 2016 to $31^{\text {st }}$ March 2018 were included in this study. Palpebral conjunctiva, tongue, nailbed and palms were examined for pallor. Hemoglobin estimation were done by Drabkin's method in all children. Anemia was defined according to WHO criteria $(\mathrm{Hb}<11 \mathrm{~g} / \mathrm{dl})$. Data was analyzed statistically. Results: Among 200 children with pallor, tongue pallor was identified in maximum (79\%), palmar pallor in minimum (61\%). Mean hemoglobin in pallor group ranged from 8.7 to $9.04 \mathrm{~g} / \mathrm{dl}$ and 10.96 to $11.1 \mathrm{~g} / \mathrm{dl}$ in no pallor group. Hemoglobin was lowest with tongue pallor $(8.7 \mathrm{~g} / \mathrm{dl})$. Children with pallor group, $160(71 \%)$ had anemia and no pallor group $140(77 \%)$ had no anemia. Maximum sensitivity and specificity were for tongue pallor (59.5\%) and palmar pallor (92.2\%) respectively and maximum predictive value was for palmar pallor (88.2\%). Conclusion: Pallor was found to be very useful in detecting anemia, also it had more specific than sensitive value. The best predictor site for pallor for diagnosing anemia was palm.

Keywords: Anemia, Children, Hemoglobin, Pallor.

Corresponding Author: Dr. Saiprasad Onkareshwar kavthekar, Associate Professor, Department of Pediatrics, D Y Patil Medical Collage, D.Y Patil Education society (Institution Deemed to be University) Kolhapur 416006, (India).

Received: December 2018

Accepted: January 2019

\section{Introduction}

Anemia is a disease in which the count of red blood cells are decreased and their oxygen-carrying capacity is not sufficient to meet the body's physiologic needs. Every person's physiological demand change with individual age, sex, area of living and altitude level. ${ }^{[1]}$ National Family Health Survey (NFHS IV) data showed that over 58\% of children below five year's of age had anemia, that is they suffer from insufficient hemoglobin in their peripheral blood. ${ }^{[2]}$ As this study was conducted in Maharashtra, as per 2015 Indian Health Report, 73.7\% children in Maharashtra had anemia aged between 6 to 59 months. ${ }^{[3]}$ Children younger than 2 years were found to have a higher prevalence of anemia as compared to older children. Iron deficiency is one of the most common causes of anemia. Early cessation of breastfeeding associated with poor complementary diet with low iron content adds a multiplier effect to the anemia. This risk is aggravated by the greater exposure to contagion from infectious and parasitic diseases, due to increased contact with the outside environment. ${ }^{[4-6]}$
The diagnosis and management of anemia largely depends on clinical assessment for pallor which is an important part of general physical examination of every children. Many medical practitioners in remote areas where there is no proper laboratory set up depend on physical signs to diagnose anemia and one of them is pallor. Pallor is explained as decreased colour of the skin and mucous membranes mainly due to decreased level of hemoglobin in blood. Generally all the parts of body are suffered because of anemia apart from, pallor is foremost seen in places where blood vessels are nearby to the surface such as palms, nail beds and mucous membranes like palpebral conjunctiva and tongue. ${ }^{[7]}$ This study was carried out to study sensitivity, specificity and predictive value of pallor at above sites in diagnosing anemia and to correlate pallor with hemoglobin in children aged 5 months to 6 years.

\section{Subjects and Methods}

In this Case Control study four hundred children out of which 200 cases and 200 controls aged between 6 months to 5 years, admitted at Department of Pediatrics, D.Y Patil 
medical college and hospital, Kolhapur from $1^{\text {st }}$ October 2016 to $31^{\text {st }}$ March 2018 were included in this study. Children having shock, edema, icterus and those who were not willing to participate were excluded from this study. The study was approved by Institutional Ethical Committee. Informed and written consent was taken from parents/guardians.

Detailed history was taken from the parents/guardians regarding the symptoms of anemia and for which child was admitted. The detailed clinical examination including general and systemic examination was done. All children were examined for pallor under day light. The Sites for pallor examination were palpebral conjunctiva, tongue, nail bed and palm. Palpebral conjunctiva was examined by everting the lower palpebral conjunctiva and pale conjunctiva were those with very or no evidence of red colour on the anterior rim, which matched the fleshy colour of the posterior aspect of palpebral conjunctiva. Tongue for pallor was examined on the dorsal surface. Nail beds without pressing was looked for nail bed pallor. Palmar surface and creases were compared with examiner's palm to detect pallor on palms.200 children with pallor at any of these four sites were selected as cases (Pallor group) and 200 children without pallor at all these four sites were selected as controls (No pallor group). After physical examination for pallor, blood samples for hemoglobin estimation were taken within 3 hours. Hemoglobin estimation was done by Drabkin's method. Anemia was defined according to World Health Organization (WHO) criteria $\left(\mathrm{Hb}<11 \mathrm{~g} / \mathrm{dl}\right.$ in 6months- 5years). ${ }^{[1]}$ The data was analysed statistically using Chi-square test where $p<0.05$ was significant. Sensitivity, specificity and predictive values were calculated for each pallor site. Hemoglobin values were estimated by mean and standard deviation. ANOVA was applied to test the significance.

\section{Results}

Four hundred children were included in this study, out of which 200 with pallor were assigned as Pallor group and 200 without pallor as No pallor group. Their age and gender distribution were shown in [Figure 1 and Table 1]. Both groups were comparable statistically.

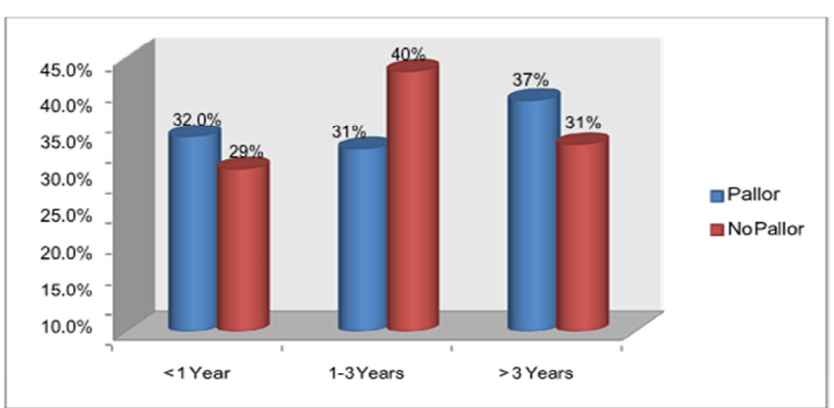

Figure 1: Age wise distribution in Pallor and No pallor group. $(\mathbf{p}=\mathbf{0 . 0 2 3})$
Table 1: Gender distribution in Pallor and No pallor group (p value $<0.001$ ).

\begin{tabular}{|l|l|l|}
\hline Sex & Pallor $(\mathbf{n}=\mathbf{2 0 0})$ & No Pallor $(\mathbf{n}=\mathbf{2 0 0})$ \\
\hline Males & $112(56 \%)$ & $103(51.5 \%)$ \\
\hline Females & $88(44 \%)$ & $97(48.5 \%)$ \\
\hline
\end{tabular}

Among 200 children with pallor group, tongue pallor was identified in maximum cases $(79 \%)$ and palmar pallor in minimum cases (61\%) [Table 2]

Table 2: Pallor at various sites in Pallor group.

\begin{tabular}{|l|l|l|}
\hline Pallor Sites & Number (N=200) & $\begin{array}{l}\text { Percentage } \\
(\mathbf{\%})\end{array}$ \\
\hline Conjunctiva & 144 & 72 \\
\hline Tongue & 158 & 79 \\
\hline Nail bed & 144 & 72 \\
\hline Palm & 122 & 61 \\
\hline
\end{tabular}

Mean Hemoglobin was found to be the lowest for patients with tongue pallor. ( $p$ value $<0.001$ ). Mean hemoglobin difference was found to be $2 \mathrm{~g} / \mathrm{dl}$ in pallor group with $\mathrm{p}$ value $<0.001$. Mean hemoglobin in pallor group at four sites ranged from 8.7 to $9.04 \mathrm{~g} / \mathrm{dl}$ and 10.96 to $11.1 \mathrm{~g} / \mathrm{dl}$ in no pallor group [Table 3]

\begin{tabular}{|c|c|c|c|}
\hline \multicolumn{4}{|c|}{ Table 3: Mean hemoglobin in Pallor and No pallor groups. } \\
\hline \multicolumn{2}{|c|}{ Pallor } & \multirow{2}{*}{$\begin{array}{l}\text { Mean } \\
\text { hemoglobin } \\
(\mathrm{g} / \mathrm{dl})\end{array}$} & \multirow{2}{*}{$\begin{array}{l}\text { SD } \\
2.07\end{array}$} \\
\hline Pallor & Present & & \\
\hline & Absent & 11.33 & 1.35 \\
\hline \multirow{2}{*}{$\begin{array}{l}\text { Conjunctival } \\
\text { pallor }\end{array}$} & Present & 8.79 & 2.06 \\
\hline & Absent & 11.11 & 1.49 \\
\hline \multirow[t]{2}{*}{ Tongue pallor } & Present & 8.71 & 2.03 \\
\hline & Absent & 10.96 & 1.63 \\
\hline \multirow[t]{2}{*}{ Nail bed pallor } & Present & 8.90 & 2.02 \\
\hline & Absent & 11.05 & 1.61 \\
\hline \multirow[t]{2}{*}{ Palmar pallor } & Present & 9.04 & 2.09 \\
\hline & Absent & 11.08 & 1.55 \\
\hline
\end{tabular}

Out of 200 children with pallor group , 160(71\%) had anemia and 200 children with no pallor group, 140(77\%) had no anemia.[Figure 2] Correlation of pallor in conjunctiva, tongue, nail bed and palm with anemia was statistically significant ( $\mathrm{p}$ value $<0.001$ ).

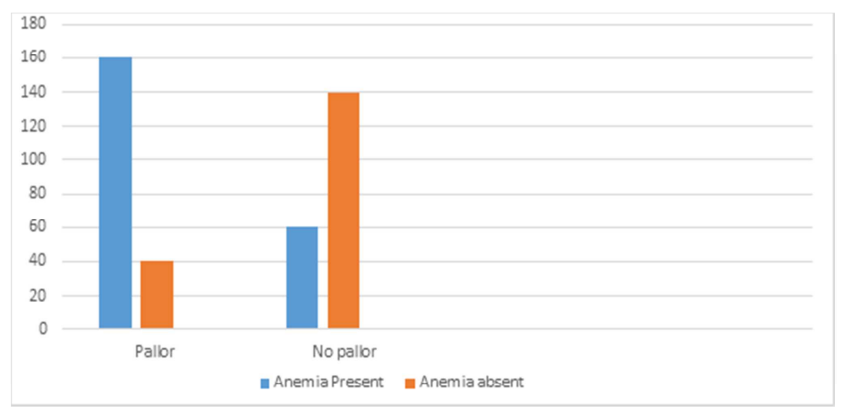

Figure 2: Correlation of Pallor with anemia in Pallor and No pallor groups 
Maximum sensitivity and specificity were for tongue pallor $(59.5 \%)$ and palmar pallor $(92.2 \%)$ respectively and maximum predictive value was for palmar pallor $(88.2 \%)$. Minimum sensitivity and specificity were for palmar (49\%) and tongue $(85 \%)$ pallor respectively. [Table 4 ]

Table 4: Sensitivity, specificity and predictive values for each
pallor site
\begin{tabular}{|l|l|l|l|l|}
\hline Pallor site & Sensitivity & Specificity & $\begin{array}{l}\text { Positive } \\
\text { Predictive } \\
\text { value }\end{array}$ & $\begin{array}{l}\text { Negative } \\
\text { Predictive } \\
\text { Value }\end{array}$ \\
\hline Conjunctiva & $55 \%$ & $87.22 \%$ & $85.80 \%$ & $61.30 \%$ \\
\hline Tongue & $59.50 \%$ & $85.0 \%$ & $82.90 \%$ & $63.20 \%$ \\
\hline Nail bed & $56.8 \%$ & $89.4 \%$ & $86.8 \%$ & $62.8 \%$ \\
\hline Palm & $49.0 \%$ & $92.2 \%$ & $88.5 \%$ & $59.70 \%$ \\
\hline
\end{tabular}

\section{Discussion}

The WHO has made it clear by referring in Integrated Management of Childhood Illness (IMNC) that if there is presence of pallor at any site it can be used as a aid to diagnose anemia, more commonly in areas where there is high prevalence of anemia. ${ }^{[8]}$ This study was conducted to assess the usefulness of pallor in children aged 6 months to 5 years, in diagnosing anemia which would be great help for Pediatricians and Medical Professionals who are working at remote areas where there is no laboratory facilities.

Majority of children with pallor and anemia belonged to the age group $<3$ yrs. $63 \%$ children with pallor and $73 \%$ of children with anemia were $<3 y$ rs. Anemia is common in this age group especially iron deficiency because of increased demands of iron and reduced oral intake along with bad feeding habits, especially during the weaning period, by introducing foods that are poor in iron and other nutrients, like vitamin B12 and folic acid.

In this study, all the four sites of pallor that is palpebral conjunctiva, tongue, nail bed and palm had statistical correlation with anemia but the best predictor site was palm. The best predictor site for pallor according to various studies is shown in [Table 5]

Table 5: Shows best predictor pallor site for anemia in various studies

\begin{tabular}{|l|l|}
\hline Studies & Best predictor \\
\hline Chandrasekaran C et al ${ }^{[9]}$ & Palm \\
\hline santra G et al ${ }^{[10]}$ & Palm \\
\hline Regina D et al ${ }^{[11]}$ & Palm \\
\hline${\text { Kalantri A et al } l^{[12]}}^{[13]}$ & Tongue \\
\hline Kalter HD et al ${ }^{[1]}$ & Conjunctiva \\
\hline Chalco JP et al ${ }^{[14]}$ & Palm and nail bed \\
\hline Present study & Palm \\
\hline
\end{tabular}

Also tongue pallor was found to be the most sensitive and palmar pallor most specific. Sensitivity was the least for palmar pallor and specificity was the least for conjunctiva and tongue. Over all pallor was found to be more specific rather than sensitive. In our study specificity ranged from
$85 \%-92.2 \%$ and sensitivity $49 \%-59.5 \%$. The sensitivity and specificity for pallor sites in various studies is shown in [Table 6]

Table 6: Sensitivity and specificity of conjunctiva, tongue, nailbed and palmar pallor for anemia in various studies

\begin{tabular}{|c|c|c|c|}
\hline Pallor site & Studies & $\begin{array}{l}\text { Sensitivity } \\
(\%)\end{array}$ & $\begin{array}{l}\text { Specificity } \\
(\%)\end{array}$ \\
\hline \multirow[t]{5}{*}{ Conjunctiva } & $\begin{array}{l}\text { Chandrasckaran C ct } \\
\mathrm{al}^{[9]}\end{array}$ & 50 & 93.8 \\
\hline & Santra G et al ${ }^{[10]}$ & 84 & 96 \\
\hline & Regina $\mathrm{D}$ et $\mathrm{al}^{[11]}$ & 48.39 & 94.53 \\
\hline & Chalco JP ${ }^{[14]}$ & 43.6 & 81.4 \\
\hline & Present study & 55 & 87.22 \\
\hline \multirow[t]{3}{*}{ Tongue } & $\begin{array}{l}\text { Chandrasekaran } \mathrm{C} \text { et } \\
\mathrm{al}^{[9]}\end{array}$ & 55 & 96 \\
\hline & Santra G et al ${ }^{[10]}$ & 88 & 93.33 \\
\hline & Present study & 59.5 & 85 \\
\hline \multirow[t]{3}{*}{ Nailbed } & $\begin{array}{l}\text { Chandrasekaran C et } \\
\mathrm{al}^{[9]}\end{array}$ & 50 & 96.2 \\
\hline & Santra G et al ${ }^{[10]}$ & 72 & 96 \\
\hline & Present study & 56.8 & 89.4 \\
\hline \multirow[t]{4}{*}{ Palm } & $\begin{array}{l}\text { Chandrasekaran C et } \\
\mathrm{al}^{[9]}\end{array}$ & 55 & 96 \\
\hline & Santra G et al ${ }^{[10]}$ & 12 & 100 \\
\hline & Regina $\mathrm{D}$ et $\mathrm{al}^{[11]}$ & 100 & 98.2 \\
\hline & Present study & 49 & 92.2 \\
\hline
\end{tabular}

Chances of missing conjunctival pallor in many patients was because of the congestion associated with febrile illness. Also because of the congestion associated with crying while palpating, during clinical examination which probably could be attributed to low positive predictive value. Pigmentation largely affects sensitivity of pallor sites especially palmar pallor. Because of racially homogenous sample, that variation was not studied by us. Also there is variation in looking for palmar pallor. It is recommended that, to look at palmar creases along with palm for palmar pallor. In our study, we compared children's palmar surfaces and creases with examiner's palm to identify for pallor.

Limitations of this study were firstly, this study was conducted in hospitalized children. This is probably one of the limitation of this study as study by Dos Santos RF et $\mathrm{al},{ }^{[15]}$ in under five children found that anemia was more prevalent among children who were hospitalized for longer periods of time $(64.2 \%)$ and concluded that anemia may contribute as a causal factor for hospitalization. Secondly there are varied opinions regarding the subjective variation of pallor in anemia. Dasilva et al, ${ }^{[7]}$ found that experience is more important in detecting pallor for anemia.

\section{Conclusion}

Pallor was found to be very useful in detecting anemia also it had more specific value than sensitive value. The best predictor site for pallor in diagnosing anemia was palm. 


\section{Chaudhary et al; Accuracy of $P$ allar in the Diagnasis of Anemia in Children}

Many thanks to all the colleagues and teachers of the Department of Pediatrics for their constant support in conducting this research study.

\section{Contributors}

AC, SK: designed the study, collected and analysed the data and drafted the manuscript.MP: supervision of work and analysed the data. BS: literature search and drafted the manuscript. All authors approved the final version of manuscript.

MP: Will act as the guarantor.

\section{References}

1. WHO. Hemoglobin concentrations for the diagnosis of anemia and assessment of severity. Vitamin and Nutrition Information System. Geneva, World Health Organization2011(WHO/NMH/NHD/MNM/11.1)

(http://www.who.int/vmnis/indicators/haemoglobin.pdf

2. National family health survey FOUR-2015-2016,table 10.12-page no.320, rchiips.org/nfhs/NFHS-4Reports/India.pdf

3. Indian health report - Nutrition 2015 Page no:313 www.transformnutrition.org/.../2015/.../INDIA-HEALTH-REPORTNUTRITION pdf

4. Oliveira MA, Osório MM, Raposo MC. Socioeconomic and dietary risk factors for anemia in children aged 6 to 59 months. J Pediatr (Rio J). 2007:83:39-46.

5. De Castro TG, Silva-Nunes M, Conde WL, Muniz PT, Cardoso MA. Anemia and iron deficiency among school children in the Western Brazilian Amazon: prevalence and associated factors. Cad Saude Publica. 2011;27:131-42.

6. Gondim SS, Diniz A da S, Souto RA, Bezerra RG, Albuquerque EC, Paiva Ade A. Magnitude, time trends and factors associate with anemia in children in the state of Paraíba, Brazil. Rev Saude Publica. 2012;46: $649-56$.
7. Da Silva RM, Machado CA. Clinical evaluation of the paleness: agreement between observers and comparision with haemoglobin levels. Rev Bras Hematol Hemoter.2010;32(6):444-8.

8. Integrated management of childhood illness (IMCI): Conclusion WHO division of child health and development . Bull World Health Organization 1997;75(suppl1):119-28 https://www.ncbi.nlm.nih.gov/

9. Chandrasekaran c, Accuracy of Clinical Pallor in the Diagnosis of Moderate and severe anemia in children 6 month to 5 years; International Journal of Contemporary MedicalResearch;July2016;3(7):2028-30 https://www.ijcmr.com/uploads/7/7/4/6/77464738/ijcmr_734_jul_2.pdf

10. Santra G. Usefulness of examination of palmar creases for assessing severity of anemia in Indian perspective: A study from a tertiary care center. Int J Med Public Health 2015;5:169-72.

11. Regina D, Sudharshan RC, Rao R. Correlation of pallor with hemoglobin levels and clinical profile of anemia in primary and middle school children of rural Telangana. Int J Contemp Pediatr 2016;3:87277

12. Kalantri A, Karambelkar M, Joshi R, Kalantri S, Jajoo U. Accuracy and reliability of pallor for detecting anaemia: a hospital-based diagnostic accuracy study. PLoS One. 2010 Jan 1;5(1):e 8545. doi :10.1371/journal.pone.0008545.

13. Kalter HD, Burnham G, Kolstad PR, Hossain M, Schillinger JA, Khan NZ, Saha S, de Wit V, Kenya-Mugisha N, Schwartz B, Black RE. Evaluation of clinical signs to diagnose anemia in Uganda and Bangladesh, in areas with and without malaria. Bull World Health Organ. 1997;75Suppl 1:103-11.

14. Chalco JP, Huicho L, Alamo C, Carreazo NY, Bada CA. Accuracy of clinical pallor in the diagnosis of anaemia in children: a meta-analysis. BMC Pediatr. Dec 2005; 8(5):46.

15. Dos Santos RF, Gonzalez ES, de Albuquerque EC, de Arruda IK, Diniz Ada S, Figueroa JN, Pereira AP. Prevalence of anemia in under fiveyear-old children in a children's hospital in Recife, Brazil. Rev Bras Hematol Hemoter. 2011;33(2):100-4. doi: 10.5581/15168484.20110028

Copyright: (C) the author(s), publisher. Asian Journal of Clinical Pediatrics and Neonatology is an Official Publication of "Society for Health Care \& Research Development". It is an open-access article distributed under the terms of the Creative Commons Attribution NonCommercial License, which permits unrestricted non-commercial use, distribution, and reproduction in any medium, provided the original work is properly cited.

How to cite this article: Chaudhary A, Kavthekar SO, Patil MA, Singh BK. Accuracy of Pallor in the Diagnosis of Anemia in Children Aged 6 Months to 5 Years. Asian J. Clin. Pediatr. Neonatol.2018;6(4):5-8.

DOI: dx.doi.org/10.21276/ajcpn.2018.6.4.2

Source of Support: Nil, Conflict of Interest: None declared 